\title{
Coumarin Derived Schiff Base Ligand-Synthesis, Characterization and Antimicrobial Study of its Metal Complexes.
}

\author{
Syeda Haseen Buvabi ${ }^{1 a}$ Vani Srinivasan ${ }^{1 b}$ Dr. Manjunatha $M^{2^{*}}$ \\ ${ }^{1}$ Department of Chemistry, Mount Carmel College, Bengaluru, Karnataka, India. \\ 2* Department of Chemistry, CMR Institute of Technology, Bengaluru, India. \\ ${ }^{1}$ haseenbuvabi@yahoo.com ${ }^{1}$ vanis2410@gmail.com 2*manjunatha.m@cmrit.ac.in
}

\begin{abstract}
:
A novel ligand was synthesized from terephthalaldehyde and o-phenylene diamine and treated with coumarin derivative to form a New Schiff base. $\mathrm{Co}(\mathrm{II}), \mathrm{Ni}(\mathrm{II})$ and $\mathrm{Cu}(\mathrm{II})$ complexes of the ligand were synthesized. ${ }^{1} \mathrm{HNMR}$ and LC-MS mass spectrometry studies were done. Antimicrobial studies were performed for the ligand and its metal complex with E.Coli and was found to be active. The ligand can be further modified and studied for its antimicrobial action in the future.
\end{abstract}

Key words: Coumarin aldehyde, Schiff base ligand, metal complexes, antimicrobial activity

\section{INTRODUCTION}

Schiff bases are compounds which are obtained by the condensation of amines and aldehydes. They have excellent antimicrobial activity because of which they are used as therapeutic agents. [1-4] Because of their azomethine group they have been found to be very good ligands as well. Among various compounds which can be synthesized as Schiff base ligands, Coumarins, Benzoxazoles and triazoles are most effective as they contribute to the stability and antimicrobial property of the resulting complex.[5-8] Among these, Coumarins and their derivatives are found to be the most common and eco-friendly compounds to be synthesized which show enhanced antimicrobial properties. Coumarins are oxygen containing heterocyclic compounds with medicinal value, present in plants. They are found to be good anticoagulating agents. [9-12] Coumarin derivatives are used in pharmaceutical industry extensively. They act as good chelating agents with many metal ions especially transition metals.[13-15] Therefore the current study focuses on the synthesis of Schiff bases of Coumarin aldehyde with terephthalaldehyde and o-phenylene diamine and their metal complexes of $\mathrm{Co}(\mathrm{II}), \mathrm{Ni}$ (II) and $\mathrm{Cu}(\mathrm{II})$.

\section{MATERIALS AND METHODS}

\section{Materials}

Resorcinol(QUALIGENS), ethyl acetoacetate(LR, SDFCL), Conc.H2SO4(SDFCL, LR), ethanol, hexamine, glacial acetic acid, diethyl ether (LR,SDFCL), ortho-phenylene diamine(LR,SDFCL), terephthalaldehyde(SLDR), Conc.HCl (SDFCL, LR), DMSO(SQ), $\mathrm{CuCl} 2 . \mathrm{H} 2 \mathrm{O}, \mathrm{CoCl} 2.6 \mathrm{H} 2 \mathrm{O}, \mathrm{NiCl} 2.6 \mathrm{H} 2 \mathrm{O}$. 


\section{Physical Measurements}

\section{NMR spectra}

Joel $500 \mathrm{MHz}$ NMR spectrometer was used to record the ${ }^{1} \mathrm{H}$ NMR Spectra of the ligand using $\left(\mathrm{CD}_{3}\right) 2 \mathrm{SO}$.

Mass spectroscopy JEOL GC mate Mass Spectrophotometer was used to record the mass spectrum of the ligand. The inlet of the sample was done by Direct Probe. Electron ionization mode was used for the fragmentation.

\section{Synthesis of 7-hydroxy-4-methylcoumarin}

$11 \mathrm{~g}(1 \mathrm{mmol})$ of resorcinol and $1.3 \mathrm{~g}$ of ethyl acetoacetate was dissolved and to that solution $12 \mathrm{ml}$ of conc. $\mathrm{H}_{2} \mathrm{SO}_{4}$ solution is added drop wise with constant stirring at $100^{\circ} \mathrm{C}$ and refluxed for 2 hours. White solid obtained on pouring the reaction mixture to crushed ice was filtered, washed with cold water and dried to get crude product. The dried product is then recrystallized from ethanol. Yield $-80 \%$, M.pt $184^{\circ} \mathrm{C}$

\section{Synthesis of 8-formyl-7-hydroxy-4methyl coumarin}

A mixture of 7-hydroxy-4-methyl-coumarin(0.025 moles,5.1g) and hexamine(0.07 moles, $9.8 \mathrm{~g}$ ) was refluxed for 1 hour in glacial acetic acid. $20 \% \mathrm{HCl}$ was added and refluxed for another 3 hours. The product was extracted with diethyl ether after cooling. The yellowcolored product formed was recrystallized from ethanol. Yield $-80 \% \mathrm{C}$ M. pt $-172^{\circ} \mathrm{C}$

Synthesis of Schiff base (I)

$5 \mathrm{~g}$ of ortho-phenylene diamine and $3.1 \mathrm{~g}$ of terephthalaldehyde was dissolved separately in ethanol. $2 \mathrm{ml}$ of glacial acetic acid was added to the above solutions after mixing them. The reaction mixture was refluxed for $6 \mathrm{~h}$ at $80^{\circ} \mathrm{C}$. Yellow solid is obtained on cooling the mixture. The dried product is recrystallized from ethanol in the hot condition. Yield- $84 \% \mathrm{M}$. pt $209^{\circ} \mathrm{C}$

\section{Synthesis of Schiff base(ligand) II from Schiff base (I)}

Dissolved $0.95 \mathrm{~g}$ of 8-formyl-7-hydroxy-4-methyl coumarin and Schiff base I in ethanol separately and mixed. The reaction mixture was refluxed for a little more than 2 hours. Added less than $1 \mathrm{ml}$ of conc. $\mathrm{HCl}$ to the reaction mixture and refluxed for 2 more hours. Brown solid is obtained on cooling the solution. It was dried and recrystallized from ethanol.Yield$75 \%$ M. pt $>310^{\circ} \mathrm{C}$

\section{Synthesis of metal complexes of $\mathrm{Cu}(\mathrm{II}), \mathrm{Ni}(\mathrm{II})$ and $\mathrm{Co}(\mathrm{II})$}

$0.36 \mathrm{~g}$ of Schiff base II and $0.08 \mathrm{~g}$ of respective metal chlorides were dissolved in hot ethanol separately and mixed.The reaction mixture was refluxed for an hour. Sodium acetate was added and refluxed for 3 hours. The product was collected by filtration, washed with distilled water followed by ethanol. The solid product was dried and recrystallized from hot ethanol.

Co(II) complex; Yield- $83 \%$ Color- brown Melting point- $>310^{\circ} \mathrm{C}$

$\mathrm{Cu}$ (II) complex; Yield-83\% Color- Green Melting point- $>310^{\circ} \mathrm{C}$

$\mathrm{Ni}(\mathrm{II})$ complex; Yield-85 Color- Yellow Melting point- $>310^{\circ} \mathrm{C}$ 


\section{Antimicrobial Assay}

The Schiff base ligand and its cobalt(II) complex were subjected to biological activity resistant to gram negative bacteria- Escherichia coli. Stock solution of the compounds $(5 \mathrm{mg} / 100 \mathrm{ml})$ was prepared by dissolving the compounds in DMSO. Disc diffusion method was used to study the activity. Agar medium was used as the culture. Since DMSO does not show any activity against the bacterial strains it was used as the control. The bacteria strains were cultured onto Muller-Hinton agar plate and incubated at $40^{\circ} \mathrm{C}$ for $24 \mathrm{~h}$.

\section{Reaction Scheme}<smiles>Oc1cccc(O)c1</smiles>

Resorcinol<smiles>CCOCC(C)=O</smiles>

ethyl acetoacetate

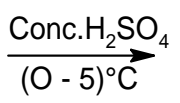<smiles>CC(=O)OC=C(C)O</smiles>

4-methyl-7-hydroxycoumarin<smiles>Cc1cc(=O)oc2cc(O)ccc12</smiles>

4-methyl-7-hydroxycoumarin<smiles>Cc1cc(=O)oc2c(C=O)c(O)ccc12</smiles>

8-formyl-7-hydroxy-4-methylcoumarin

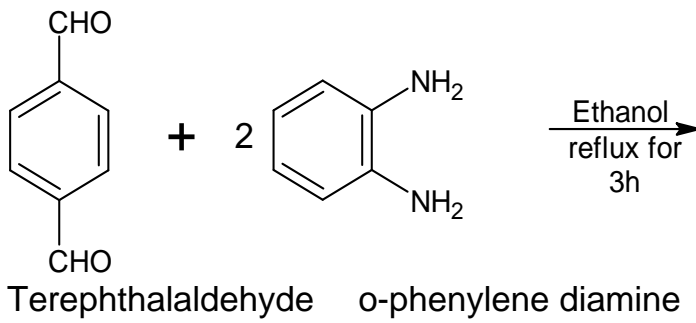<smiles>Nc1ccccc1/N=C/c1ccc(/C=N/c2ccccc2N)cc1</smiles>
methanylylidene-(E)-azanylylidene]\}dianiline<smiles>Cc1cc(=O)oc2c(C=O)c(O)ccc12</smiles>

8-formyl-7-hydroxy -4-methyl coumarin

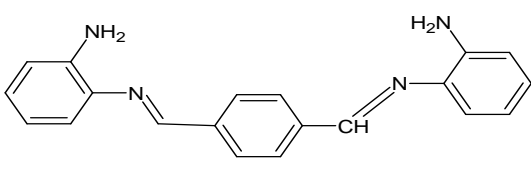

(N1,N1'E,N1,N1'E)-N1,N1'-(1,4-phe nylenebis(methanylylidene))bis(ben zene-1,2-diammine)(L2)

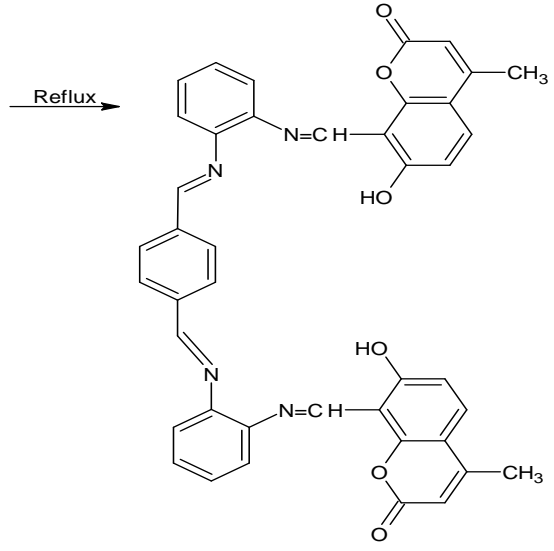

1,4-diethenylbenzene-8-[(1E)-[(2-aminophenyl)im ino]methyl]-7-hydroxy-4-methyl-2H-chromen-2-on e-8-[(1E)-[(2-aminophenyl)imino]methyl]-7-hydrox 


\section{RESULTS AND DISCUSSION}

The metal complexes of $\mathrm{Co}(\mathrm{II}), \mathrm{Ni}(\mathrm{II})$ and $\mathrm{Cu}(\mathrm{II})$ with the above ligands were reported for the first time. The ligand was soluble in and DMSO hot ethanol, whereas, its metal complexes were found to be soluble only in DMSO. Schiff base and its metal complexes were coloured solids with reasonably good yield. Melting point of ligand is lesser than that of the complexes indicating the enhancement of stability on complexation. ${ }^{1} \mathrm{H}$ NMR and Mass spectroscopy were used to characterize the ligand. Antimicrobial studies were conducted on both ligand and complex.

\section{Characterization of Ligand}

\section{NMR ( ${ }^{1}$ H NMR) spectral study}

The ${ }^{1} \mathrm{H}$ NMR spectra of the 8-formyl-7-hydroxy-4-methylcoumarin and Schiff base ligands was recorded in Joel $400 \mathrm{MHz}$ NMR spectrometer using DMSO as the solvent.

\section{${ }^{1}$ H NMR spectrum of 8-formyl-7-hydroxy-4-methylcoumarin}

Signals corresponding to 6 types of protons are observed. Three singlets at 2.49, 6.29 and 10.433 attributed to $\mathrm{C} 3-\mathrm{CH}_{3}(3 \mathrm{H}), \mathrm{C} 3-\mathrm{H}(1 \mathrm{H})$ and $\mathrm{CHO}(1 \mathrm{H})$. Two doublets at 6.954-6.977 and 7.918-7.941 attributed to $\mathrm{C} 6-\mathrm{H}(1 \mathrm{H}), \mathrm{C} 5-\mathrm{H}(1 \mathrm{H})$. The NMR spectra of 8-formyl-7hydroxy-4-methylcoumarin shown in Figure1.

\section{${ }^{1}$ H NMR spectrum of Schiff base I}

Signals corresponding to 8 types of protons are observed. One singlet at $8.4 \mathrm{ppm}$ attributed to azomethine proton. One doublet due to amine proton appeared at 5.759. The protons which are para to amine group appeared as multiplet. Aromatic protons appeared as many doublets and multiplets in the region 7-8ppm. The NMR spectra of Schiff base I shown in Figure 2.

\section{${ }^{1}$ H-NMR spectrum of Schiff base(ligand) II}

Signals corresponding to 13 types of protons are observed. One singlet due to azomethine proton appeared at $8.5 \mathrm{ppm}$. One doublet due to methyl proton appeared at $2.4 \mathrm{ppm}$. One more azomethine proton attached to coumarin moiety appeared at $7.3 \mathrm{ppm}$. One multiplet due to $\mathrm{OH}$ proton appeared at $11.9 \mathrm{ppm}$. Aromatic protons appeared as many doublets and multiplets in the region 6.1-7.9ppm. The $500 \mathrm{MHz}$ NMR spectra of Schiff base II shown in Figure 3.

\section{Mass spectrum of Schiff base (ligand) II}

The mass spectrum of the compound showed molecular ion peak $\left[\mathrm{M}^{+}\right]$at 723.414 , corresponding to the molecular weight of the Schiff base formed. The molecular formula of the compound is $\mathrm{C}_{42} \mathrm{H}_{34} \mathrm{O}_{8} \mathrm{~N}_{4}$. 


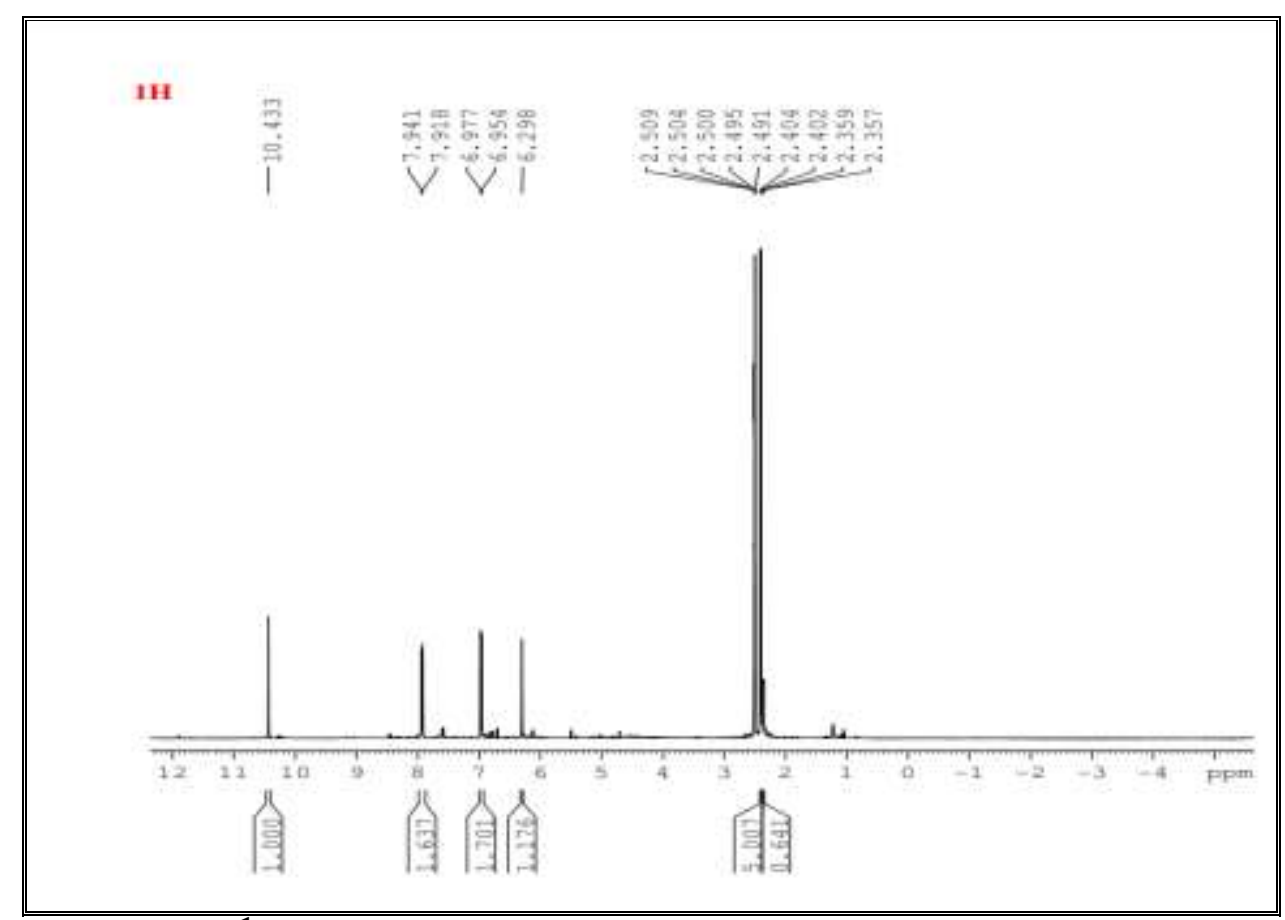

Fig 1; ${ }^{1} \mathrm{H}$ NMR spectra of 8-formyl-7-hydroxy-4-methylcoumarin

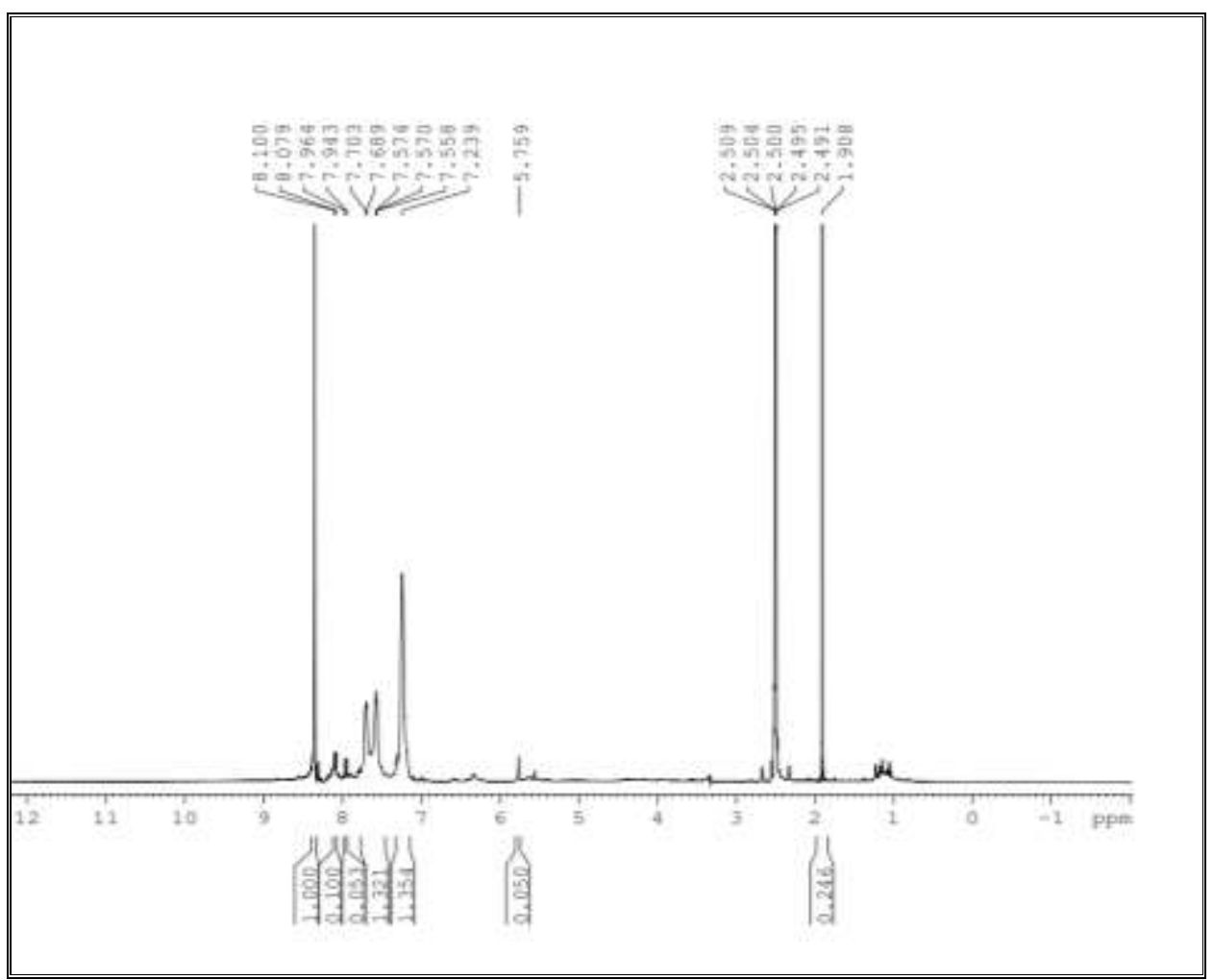

Fig 2 ; 1H NMR spectra of Schiff base I 


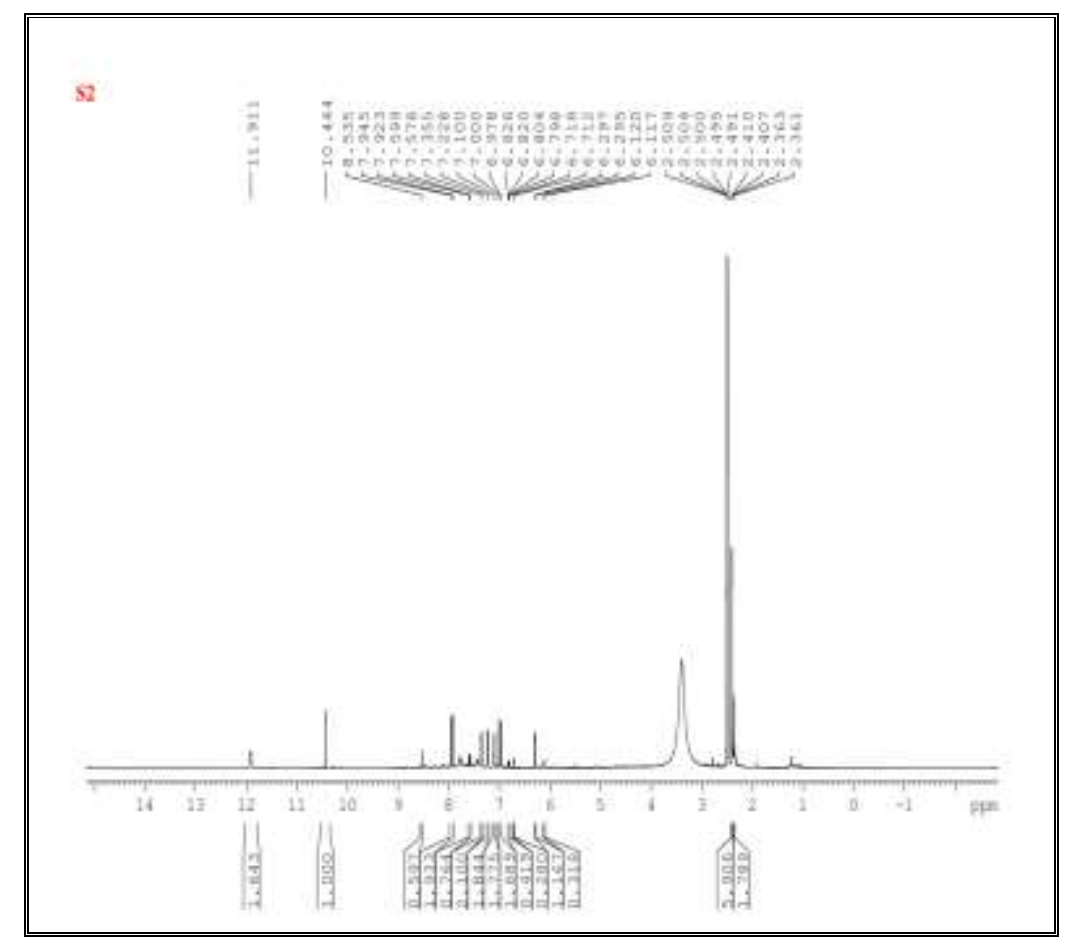

Fig $3 ;{ }^{1}$ H NMR spectra of Schiff base (ligand)II

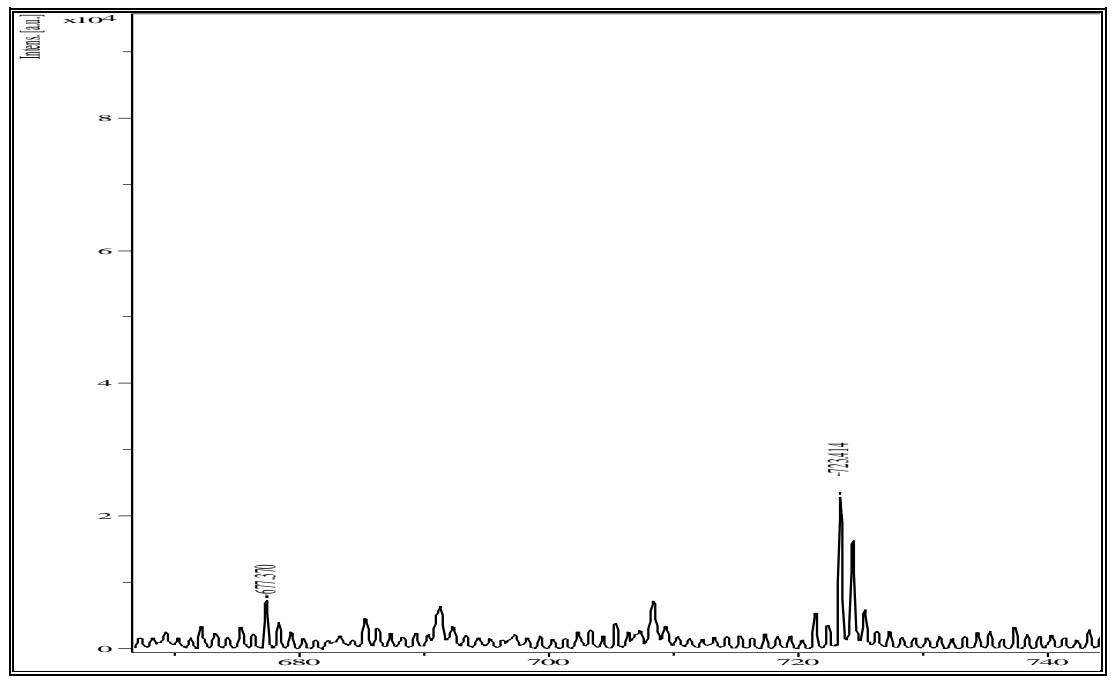

Fig 4(i); Mass spectrum of Schiff base (ligand) II 


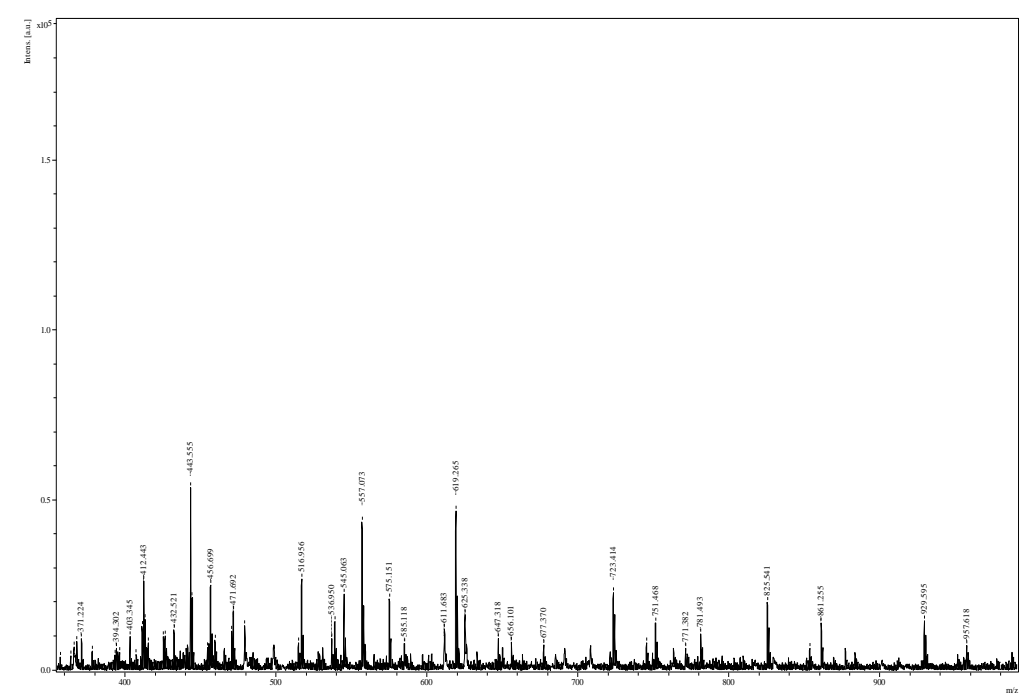

Fig 4(ii); Mass spectrum of Schiff base(ligand) II

\section{Antimicrobial activity}

According to the outcome, the zone of inhibition for new Schiff base ligand was $1.5 \mathrm{~cm}$ and zone of inhibition for Schiff base metal complexes was not distinct, this showed that the antimicrobial activity of the metal complex of copper(II) metal ion towards the gram-negative bacteria- Escherichia coli was lesser than the free Schiff base ligand. This shows that the newly synthesized Schiff base ligand are biologically active compound.

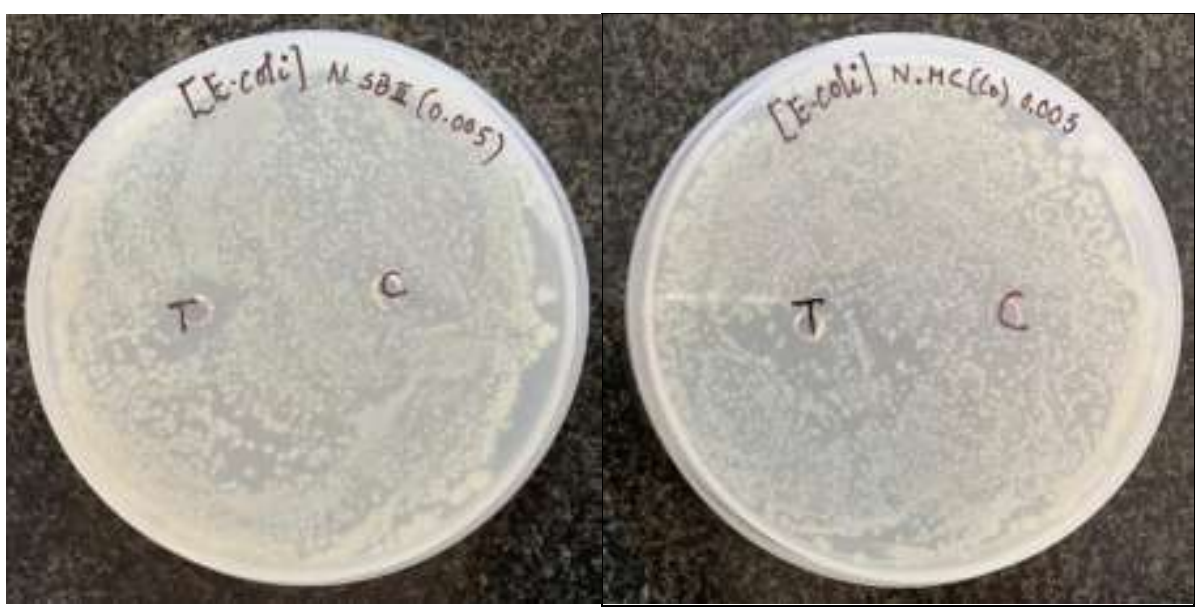

(a)

(b)

Fig 5 ; (a)Antimicrobial activity of new Schiff base ligand, (b)Antimicrobial activity of Schiff base metal complexes of $\mathrm{Co}$ (II)

\section{Conclusion}

A novel macro cyclic ligand with high flexibility was synthesized and has been confirmed by NMR and Mass spectroscopy. Antimicrobial activity of the ligand and its $\mathrm{Co}$ (II) complex were examined against gram-negative bacteria-Escherichia coli. The free ligand was found to 
be more effective against the bacteria than the metal complex. Further studies can be done with the ligand and other metal complexes in the future.

\section{AKNOWLEDGEMENT}

This work was supported by Research Centre, Mount Carmel College. We also acknowledge the support rendered by IISc, Bengaluru, for characterization of the Schiff Base and the ligand.

\section{REFERENCES}

1. Pandeya, S. N.; Sriram, D.; Nath, G.; Declercq, E. Eur. J. Pharmacol. 1999, 9, 25.

2. Pannerselvam, P.; Nair, R. R.; Vijayalakshmi, G.; Subramanian, E. H.; Sridhar, S. K. Eur. J. Med. Chem. 2005, 40, 225.

3. Sithambaram Karthikeyan, M.; Jagadesh Prasad, D.; Poojary, B.; Subramanya Bhat, K. Bioorg. Med. Chem. 2006, 14, 7482.

4. Sridhar, S. K.; Saravan, M.; Ramesh, A. Eur. J. Med. Chem. 2001, 36, 615.

5. Mr. Sopan T. Adhao, Dr. Rahul R. Wagh, IJPPR, ISBN 2349-7203

6. Angela Stefanachi, Francesco Leonetti, Leonardo Pisani, Marco Catto and Angelo Carotti, Molecules,2018,23,250.

7. Chavan, O. S., \& Baseer., Der Chemica Sinica, 2014, 5(5):67-70

8. Thangadurai, T. D.; Gowri, M.; Natarajan, K. Synth. React. Inorg. Met.-Org. Chem. 2002, $32,329$.

9. Schonberg, A.; Latif, N. J. Am. Chem. Soc. 1954, 76, 6208.

10. Ramesh, R.; Sivagamasundari, M. Synth. React. Inorg. Met.-Org. Chem. 2003, 33, 899.

11.Kajal, A., Bala, S., Kamboj, S., Sharma, N., \& Saini, V, Journal of Catalysts,2013, 1-14.

12.Mahmoud, M. J., Numan, A. T., \& Al-Obaidi, O. B. M. S, Journal of Al-Nahrain

University,2013, (Vol. 16)

13. Shaygan, S., Pasdar, H., Foroughifar, N., Davallo, M., \& Motiee, F, Applied Sciences (Switzerland), 2018,8,85

14. Sree, D. R., \& Sudha Kumari, S,IJERT, 2020.

15.Yusuf, S. S., Salga, M. S., Sani, M., \& Addresses, E, Science World Journal,2018, 13(4). 